34. Данілін А., Слюсаренко А. Архітектура і стратегія. Інь і Янь інформаційних технологій підприємства /А.Данілін, А.Слюсаренко // М .: Інтернет-Ун-т Інформ. Технологій. 2005. 504 с.

35. Крисанов С. П. Інвестиції в інформаційні технології / С.П. Крисанов // [Електронний ресурс]. //Електронне джерело// 2017. URL: http://naukoznanie.ru/PDF/1-9.pdf (дата звернення: 13.11.2018).

36. Сазонець О. М. Визначення ефективності інвестиційного проектування в інформаційні технології / О.М. Сазонець // Економіка і регіон. 2009. №4(23). С. 148-151.

37. Шипунова О. В. Аналіз чинників ризику на різних етапах створення інформаційних систем / O.B. Шипунова //[Електронний ресурс]. // Електронне джерело// 2017. URL: http://dspace.uabs.edu.ua/ (дата звернення: 13.10.2018).

38. Мосіна Є. І. Інвестування в інформаційні технології / Є.І. Мосіна // Економіка підприємства. Вісник ОрелГІЕТ. 2011. №2 (16). С. 39-41.

39. Редькіна С. Ефективність інформаційних технологій в бібліотеках / С. Редькіна // Бібліосфера. 2011. № 2. C.24-31.

УДК 339.138

JEL classification: M21, I12, L65

Артеменко Л.П.,

канд. економ. наук, доцент ORCID ID: 0000-0002-8585-0252

Пічугіна М.А.

канд. економ. наук

ORCID ID: 0000-0003-3072-9137

Артеменко 0.T.

Національний технічний університет Украӥни «Київський політехнічний інститут імені Ігоря Сікорського»

\title{
БЕНЧМАРКІНГ КОНКУРЕНТОСПРОМОЖНОСТІ ФАРМПІДПРИЕМСТВ НА ЄВРОПЕЙСЬКОМУ РИНКУ
}

\section{BENCHMARKING OF PHARMACEUTICALS COMPETITIVENESS IN THE EUROPEAN MARKET}

У статті на основі узагальнення теоретичних підходів до організації бенчмаркінгу розроблено практичний алгоритм для підвищення конкурентоспроможності фармацевтичних підприємств на європейському ринку. Визначено тенденції та прогнози розвитку вітчизняного фармацевтичного ринку. Серед зарубіжних ринків обирано європейський фармащевтичний ринок для порівняння, узагальнено дані про головні фармацевтичні компанії обраної групи, їхні процеси (продукиіі). Проаналізовано практику украйнських фармачевтичних компаній, які намагаються закріпитися на європейському ринку. Підкреслено, щуо ефективне здійснення бенчмаркінгу неможливе без комплаєнтного підходу (відповідність бізнес-етиці, внутрішнім та зовнішнім вимогам та правовим нормам). Представлено алгоритм бенчмаркінгу конкурентоспроможності для вітчизняних фармпідприємств. На першому етапі «Планування» визначено тендениії та прогнози розвитку вітчизняного ринку. На другому етапі «Збір даних» серед зарубіжних ринків обирано європейський фармачевтичний ринок для порівняння, збирано дані про головні фармкомпанії обраної групи, їхніх прочесах (продукиії), про власні процеси (продукиію) компаніі. Третій етап «Аналіз» проведено на основі оцінки рівня 
ефективності власної ци порівнюваних компаній; ідентифікації розриву у рівні ефективності за основними аналізованими продуктами. На четвертому етапі "Реалізачія» означено план дій. Запропоновано здійснювати контроль та оцінку бенчмаркінгу за показниками: ефективність зовнішньоторговельної угоди; вплив запропонованих заходів на коефічієнт конкурентоспроможності організації; вплив запропонованих заходів на загальні економічні показники діяльності організації $i$ при оцінюванні отриманого результату порівняти реальні показники $i$ прогнозовані. Практичне значення дослідження полягає в можливості розвитку зовнішньоекономічної діяльності підприємства фармачевтичної галузі з використанням бенчмаркінгу для підвищення конкурентоспроможності підприємства на зовнішніх ринках. Зроблено висновки та визначено перспективи подальших досліджень.

Ключові слова: бенчмаркінг, фармпідприємства, європейський ринок.

In the article, a practical algorithm for increasing the competitiveness of pharmaceutical companies in the European market was developed based on the generalization of theoretical approaches to the organization of benchmarking. The trends and forecasts of the development of the domestic pharmaceutical market were determined. Among the foreign markets, the European pharmaceutical market is selected for comparison; data on the main pharmaceutical companies of the selected group, their processes (products) were generalized. The practice of Ukrainian pharmaceutical companies, which are trying to consolidate the European market, are analyzed. It was emphasized that effective implementation of benchmarking is impossible without a compliant approach (compliance with business ethics, internal and external requirements and legal norms). An algorithm for benchmarking competitiveness for competitive pharmaceutical companies was presented. On the first stage of "Planning", the tendencies were predicted to forecast the development of the competitive market. At the second stage of "Data Collection" among overseas markets, the European pharmaceutical market was selected for data comparison on the main pharmaceutical companies of the selected group, their processes (products), own processes (products) of the company. The third stage of the "Analysis" was based on the assessment of the level of efficiency of their own and compared companies; identification of the gap in the level of efficiency of the main analyzed products. In the fourth stage, "Implementation", an action plan was indicated. It was proposed to control and evaluate benchmarking by indicators: efficiency of foreign trade agreement; the impact of the proposed measures on the coefficient of competitiveness of the organization; the impact of the proposed measures on the overall economic performance of the organization and to compare real indicators and predicted. The practical significance of the study is the possibility of foreign economic activity development of the pharmaceutical industry with the use of benchmarking to improve the competitiveness of the company in foreign markets. Conclusions and prospects of further researches were made.

Key words: benchmarking, pharmaceuticals, European market.

Вступ. Актуальність використання моделі бенчмаркінгу для вітчизняної фармації пояснюється тим, що вона відноситься до найбільш високотехнологічних і зростаючих секторів економіки та при відповідних умовах (у тому числі правильному застосуванні ефективних управлінських інструментів) може стати локомотивом розвитку економіки. Фармацевтичний ринок Європи відноситься до провідних світових регіональних ринків; якщо українські компанії розглядають його як стратегічний, то для них орієнтиром мають бути не власні досягнення, а найкраща практика іноземних конкурентів. Фармпідприємства повинні володіти інформацією про вдало 
працюючих конкурентів для досягнення оптимальних результатів роботи своєї компанії. Одним із методів встановлення конкурентних переваг $\epsilon$ бенчмаркінг, тобто процес різнопланового порівняння компанії з тими, що досягли більш значних успіхів, або зайняли лідерські позиції в тій самій галузі, або за їі межами. Як наслідок такого процесу, імплементують заходи, направлені на нівелювання розриву між підприємством-реформатором та лідером у певному напрямі [1]. Відповідно, розроблення практичних рекомендацій щодо здійснення бенчмаркінгу для підвищення конкурентоспроможності вітчизняних фармпідприємств на ринку Європи є актуальним науково-практичним завданням.

Постановка завдання. Метою роботи є обгрунтування пропозицій щодо проведення процесу бенчмаркінгу для підвищення конкурентоспроможності на європейських ринках. Реалізація даної мети передбачає розв'язання наступних завдань: узагальнити теоретичні підходи до організації бенчмаркінгу i розробити практичний алгоритм для підвищення конкурентоспроможності фармпідприємств на європейському ринку.

Методологія. $\mathrm{Y}$ процесі дослідження було використано загальнонаукові методи, а саме: аналізу та синтезу, індукції та дедукції, якісного та кількісного аналізу. Теоретичною основою дослідження є роботи провідних зарубіжних та вітчизняних вчених, що присвячені питанням організації бенчмаркінгу.

Результати дослідження. Бенчмаркінг являє собою метод управління ефективністю різних сфер діяльності (виробництва, збуту, фінансів, логістики, кадрової політики та ін.), заснований на порівняльному аналізі роботи компанії з кращими представниками галузі (або інших галузей), який полягає в оцінці власної і галузевої ефективності, ідентифікації та вивченні роботи галузевих лідерів i впровадженні найкращих досягнень у свою діяльність. Завдання бенчмаркінгу полягають у наступному: визначення конкурентоспроможності компанії та іiі слабких сторін; усвідомлення необхідності змін; добір ідей щодо кардинального поліпшення бізнеспроцесів; виявлення найкращих прийомів роботи для компанії цього типу; розроблення інноваційних підходів до вдосконалення бізнес-процесів; сприяння постановці «довгострокових» цільових показників якості роботи, котрі значно перевищують поточні; розроблення нових заходів 3 метою підвищення ефективності роботи якості послуг, що надаються; переорієнтування корпоративної культури та ментальності [2].

\section{Головними проблемами бенчмаркінгу} підвищення конкурентоспроможності підприємства $є$ наступні [3]: вітчизняні підприємства складно порівнювати 3 зарубіжними, оскільки різні управлінські підходи та діловодство не дають змоги сформувати адекватні співставні показники у глобальному охопленні; не коректне усвідомлення інструментів та призначення бенчмаркінгу; недостовірність даних фінансової звітності; недостатність ефективних методів управління. 
Кваліфіковане використання бенчмаркінгу, а також наявність досвідчених фахівців може призвести до: покращення результатів роботи; зменшення затрат на власні розробки (стратегії i процеси) шляхом застосування та удосконалення інших; у бенчмаркінгу партнерів встановлення довірливих відносин між компаніями; постійне вдосконалення функціонування організації шляхом регулярного співставлення елементів діяльності з такими самими підходами значно успішнішої діяльності на мікро- та макрорівнях. Проте, застосування бенчмаркінгу не є гарантією здобутків. Для успішних результатів використання бенчмаркінгу необхідна особлива культура [4], стимулюючі зміни, проактивність. Іншими словами, в організації, яка використовує бенчмаркінг, необхідне підприємницьке лідерство [5]. Інформація і знання мають цінність тільки при забезпеченні їх широкої імплементації в діяльності підприємства і партнерських відносинах. Та інформація, яка не може бути реалізована на комерційній основі, має давати ефект у вигляді розширення доступу до знань i можливостей реалізації результатів своєї діяльності, що безпосередньо пов’язано 3 підвищенням конкурентоспроможності.

Представимо алгоритм бенчмаркінгу конкурентоспроможності для вітчизняних фармпідприємств.

На першому етапі «Планування» визначено тенденції та прогнози розвитку вітчизняного ринку. 31 травня 2016 р., парламент прийняв закон, який передбачає спрощену реєстрацію лікарських продуктів, які реєструються компетентними органами США, Швейцарії, Японії, Австралії, Канади, Свропейського Союзу відповідно до централізованої процедури. Такі лікарські продукти повинні бути прийняті для використання на території зазначених країн або членів ЄС. Також, 2016 р. став роком першого досвіду централізованих державних закупівель лікарських засобів i виробів медичного призначення через спеціалізовані міжнародні організації, а децентралізовані закупівлі були передані системі «Рrozorro». 31 квітня 2017 p. діє нова урядова програма «Доступні ліки». Ціна на лікарські засоби, які відшкодовує держава, має бути обгрунтованою. Дуже часто ціни на одні й ті самі ліки в Україні є значно вищими, ніж у сусідніх країнах.

Фармацевтичний ринок України продовжує відновлення. Купівельна спроможність населення продовжує зростати зі зростанням рівня заробітної плати, роздрібна торгівля буде рости в грошовому та натуральному вираженні. Негативним фактором є нестабільність національної валюти. За проекції ProximaResearch, ринок буде рости на 14-18\% в грошовому вираженні і на 2,9\% в натуральному вираженні [6]. Серед основних проблем поточного стану українського фармацевтичного ринку можна виділити стан економіки, низьку платоспроможність споживачів і недосконалість законодавчого регулювання галузі, валютні ризики, корупція, недостатня підтримка з боку держави, посилення ринкової конкуренції, зростання витрат на виробництво і реалізацію продукції, висока частка фальсифікату [7]. 
Факторами поліпшення фармацевтичного ринку на майбутнє є зміна моделі ціноутворення на лікарські засоби, введення реімбурсації, зміни в політиці Антимонопольного комітету, податкові зміни, запровадження комплаєнс політики, перехід на новий Національний перелік лікарських засобів, сфери державних закупівель.

На другому етапі проведення бенчмаркінгу «Збір даних» серед зарубіжних ринків обираємо європейський фармацевтичний ринок для порівняння, збираємо дані про головні фармкомпанії, їхні процеси (продукцію. Згідно зі звітом «World Preview 2018, Outlook to 2024» аналітичної компанії «Evaluate Pharma», світова фармацевтична індустрія продовжує набирати обертів. В період 2018-2024 pp. середньорічний темп приросту (Compound Annual Growth Rate - CAGR) світового ринку рецептурних препаратів складе 6,4\% (Рис.1).

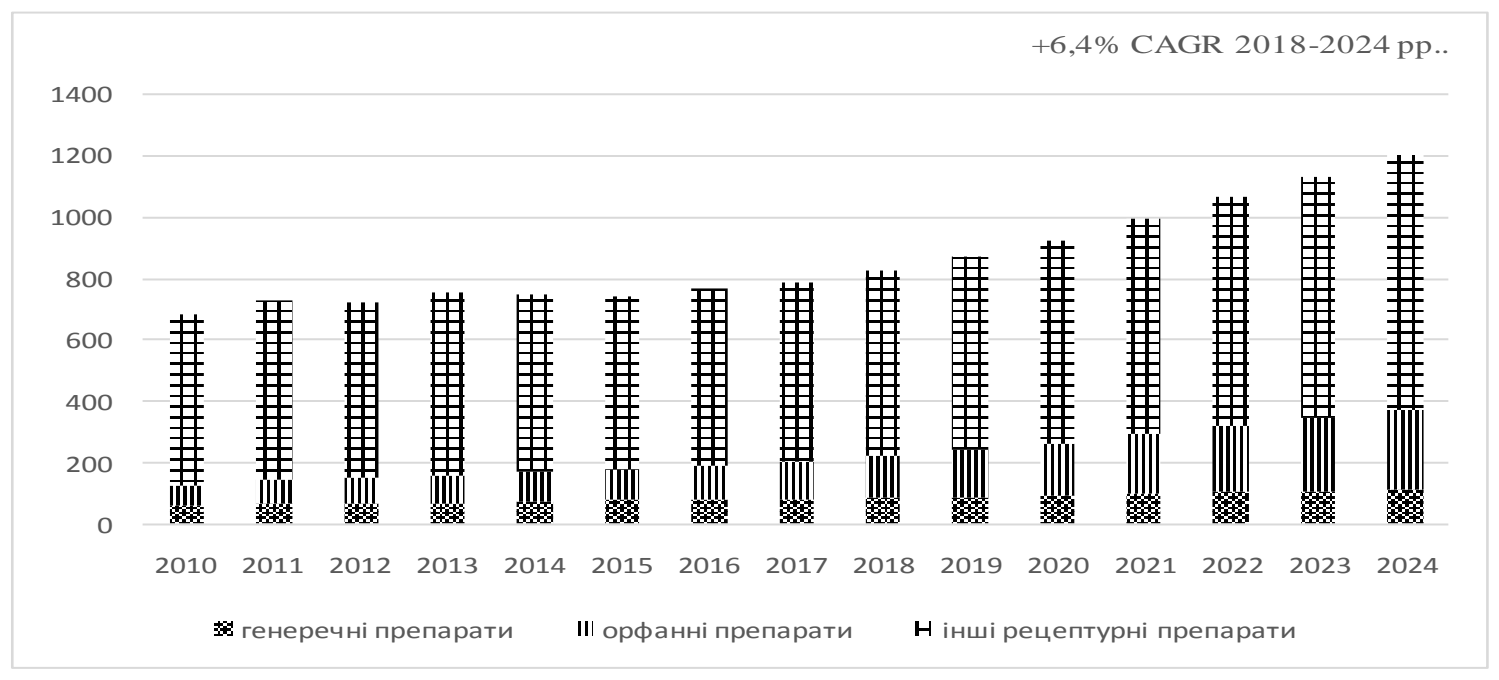

Рисунок 1 - Обсяг світових продажів рецептурних препаратів і прогноз до 2024 р., млрд. дол.США [8]

До 2024 року обсяг продажів досягне 1,2 трлн дол. США завдяки збільшенню доступу світового населення до лікарських засобів, а також лонча (нові препарати на ринку) нових методів лікування, що покривають незадоволені медичні потреби (включаючи препарати для генної та клітинної терапії) [8].

Одним із провідних світових регіональних ринків $є$ фармацевтичний ринок Європи, незважаючи на те, що його частка на світовому ринку за останні 10 років почала знижуватись. У 2003 р. вона становила 47,7\%, а у 2012 p. - 14\%. За прогнозними даними у 2020 р. вона становитиме 10\% [8].

Розвиток європейського фармацевтичного ринку нерівномірний, однак рівень достатньо високий, що свідчить про значний потенціал європейської фармацевтичної промисловості. Лідерами європейського фармринку є п'ять країн, сукупний обсяг продажів яких становить більше $40 \%$ ринку. Це ринки Німеччини, Франції, Великобританії, Італії й Іспанії (EU-5). Лідерами за обсягом продажів фармацевтичної продукції $є$ Німеччина та Франція. 
Характерною особливістю фармацевтичного ринку $\mathrm{CC} є$ те, що у структурі фармринків країн $Є С$ (навіть серед найбільших світових виробників) показники імпорту перевищують за часткою обсяг продукції локального виробництва (рис.2).

Одним з факторів, що дозволяють європейській фармацевтичній галузі зберігати зростання, є тенденція, яка пов'язана із процесами консолідації, злиттів і поглинань (M\&A). Цей процес здійснюється компаніями для розширення бізнесу й виходу на нові ринки, а також для пошуку нових технологій розробки й досліджень лікарських препаратів. M\&A сприяють розширенню присутності компаній на раніше не охоплених ринках, а також дають можливість отримати нові технологічні платформи й напрацювання в певних «вузьких» сегментах, що $є$ актуальним для України.

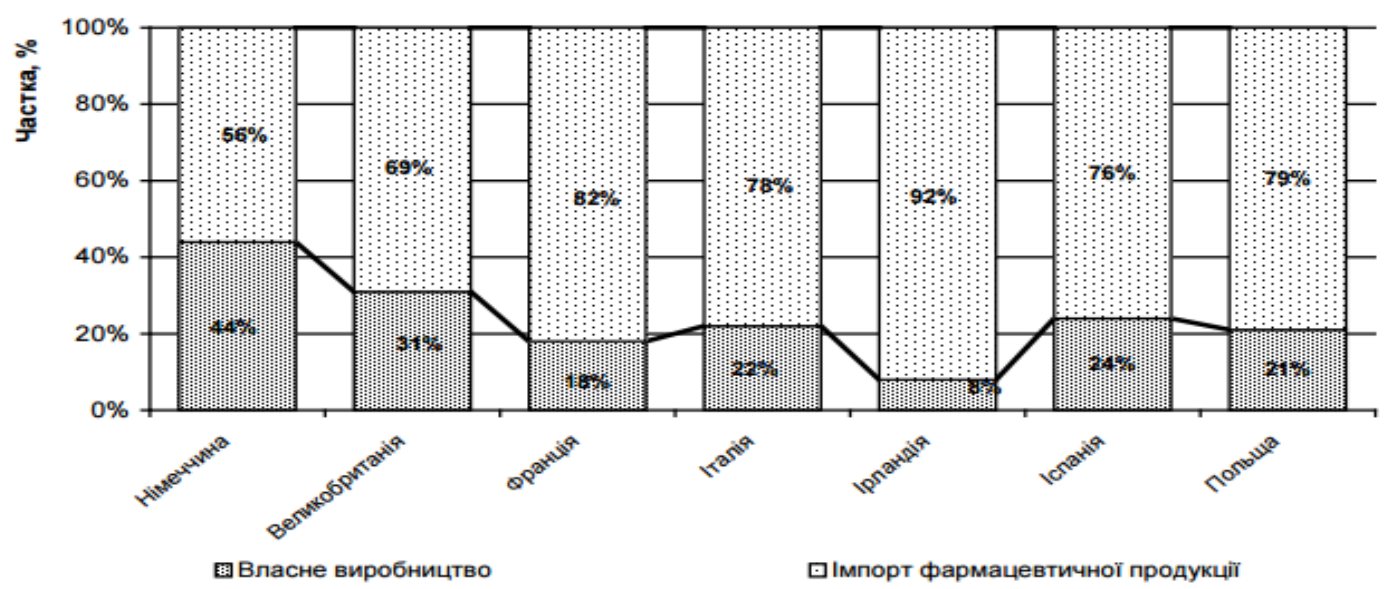

Рисунок 2 - Структура фармринків деяких країн $Є С$ у розрізі продукції локальних і закордонних виробників Складено за даними [9]

У перспективі найближчих трьох років очікується зникнення в Україні ринку брендованих генериків - відбудеться трансформація в ринок звичайних генериків. Однак неминучий відхід 3 фармацевтичного ринку компаній, внаслідок різкого зниження купівельної спроможності, а також сприйняття державою іноземних компаній виключно в розрізі здешевлення їх продукції [8].

Tретій eтап «Аналіз» доцільно проводити на основі оцінки рівня ефективності власної й порівнюваних компаній; ідентифікації розриву у рівні ефективності за основними аналізованими продуктами та аналіз причин (чинників) розриву в рівні ефективності; пошук шляхів i розробка рекомендацій з усунення розриву в рівні ефективності. Завдяки досягненням в області науки і техніки, європейська фармацевтична промисловість входить в нову еру в розвитку лікарських засобів. Інноваційна фармацевтична промисловість спрямована перетворити фундаментальні дослідження в інноваційні лікування, які широко доступні і доступні для пацієнтів. Основні кроки в біофармацевтичних дослідженнях дозволили знизити рівень смертності, наприклад від ВІЛ/СНІД, і число ракових захворювань. 
Проведення четвертого етапу «Реалізація»: здійснення змін у процесах (продукції) компанії з метою підвищення ефективності; може бути у вигляді окремих заходів або впровадження плану дій, що мають управлінський, організаційний, фінансовий, технічний, маркетинговий або інший характер. Розглянемо ТОП-10 провідних компаній України з обсягу аптечних продажів лікарських засобів (табл. 1).

Таблиця 1- ТОП-10 фармацевтичних компаній з обсягу продажів лікарських засобів в грошовому вираженні станом на серпень 2018 рік

\begin{tabular}{|c|c|c|c|c|}
\hline Фармацевтичні виробники & 2016 & 2017 & 2018 & $\begin{array}{c}\text { Зміна конкурентної } \\
\text { позиції }\end{array}$ \\
\hline Фармак (Україна) & 1 & 1 & 1 & Без змін \\
\hline Корпорація «Артеріум» (Україна) & 3 & 3 & 2 & +1 \\
\hline Дарниця (Україна) & 2 & 2 & 3 & -1 \\
\hline Теvа (Израїль) & 5 & 5 & 4 & +1 \\
\hline Sanofi (Франція) & 4 & 6 & 5 & +1 \\
\hline Berlin-Сhemie (Німеччина) & 6 & 4 & 6 & -2 \\
\hline «Здоров'я» (Україна) & 7 & 7 & 7 & Без змін \\
\hline Юрія-Фарм (Україна) & 9 & 9 & 8 & +1 \\
\hline КRКА (Словенія) & 11 & 10 & 9 & +1 \\
\hline Київський вітамінний завод (Україна) & 8 & 8 & 10 & -2 \\
\hline
\end{tabular}

Складено за даними [6]

Проаналізуємо досвід змін українських фармацевтичних виробників протягом 2016-2017 років (табл. 2, 3).

Таблиця 2 - Стратегічні зміни українських фармацевтичних виробників в $2016-2017 \mathrm{pp}$.

\begin{tabular}{|c|l|}
\hline $\begin{array}{c}\text { Фармацевтичні } \\
\text { виробники }\end{array}$ & \multicolumn{1}{|c|}{ Стратегічні зміни вітчизняних фармацевтичних компаній } \\
\hline $\begin{array}{c}\text { Галичфарм } \\
\text { «Артеріум») }\end{array}$ & Запустила лінію інфузійних розчинів. \\
\hline Інтерхім & $\begin{array}{l}\text { 17 травня відкрив нову лабораторію і виробничий комплекс в Одесі. } \\
\text { Компанія вклала 42 млн. євро в підвищення своїх виробничих } \\
\text { потужностей, що дозволить збільшити прибуток в 4 рази. }\end{array}$ \\
\hline Дарниця & $\begin{array}{l}\text { На початку 2017 року, було схвалено придбати більше 50\% акцій } \\
\text { Борщагівського Хіміко-фармацевтичного заводу (БХФ3). }\end{array}$ \\
\hline Кусум Фарм & $\begin{array}{l}\text { Розширив свій завод в Сумах, який збільшив свою виробничу } \\
\text { потужність в 2 рази. }\end{array}$ \\
\hline Фармаско & $\begin{array}{l}\text { У травні відкрила свій власний комплекс, який включає в себе офіси, } \\
\text { склади з відповідними температурними умовами і приміщеннями для } \\
\text { власного виробництва. }\end{array}$ \\
\hline Екофарм & $\begin{array}{l}\text { У 2016 році було надано банком в кредит 3,8 млн. дол. для } \\
\text { будівництва GМР заводу. }\end{array}$ \\
\hline
\end{tabular}

Джерело: [7]

Українські фармацевтичні компанії намагаються закріпитися на європейському ринку. Для збільшення частки експортних продажів i виведення своєї продукції в країни $\mathrm{CC}$, вітчизняні фармвиробники скуповують активи невеликих іноземних компаній. 
Таблиця 3 - Огляд напрямів змін українськими фармацевтичними виробниками на зовнішніх ринках протягом 2016-2017 рр.

\begin{tabular}{|c|c|}
\hline $\begin{array}{c}\text { Українські } \\
\text { фармацевтичні } \\
\text { виробники }\end{array}$ & $\begin{array}{c}\text { Напрям змін провідними вітчизняними фармацевтичними компаніями } \\
\text { на зовнішніх ринках }\end{array}$ \\
\hline $\begin{array}{l}\text { Київмедпрепарат } \\
\text { («Артеріум») }\end{array}$ & $\begin{array}{l}\text { У вересні } 2016 \text { р. придбала словенську фармацевтичну компанію } \\
\text { «Marifarm». }\end{array}$ \\
\hline Фармак & $\begin{array}{l}\text { У січні } 2016 \text { р. придбав польського дистриб'ютора KWW Kotkowski } \\
\text { Wierzbicki Wegrzyn sp.j, що дозволить продавати ЛЗ у Свропі. } \\
\text { У жовтні } 2016 \text { p. компанія оголосила про плани виходу на } \\
\text { Малазійський ринок в } 2018 \text { році. У грудні 2016 p. компанія } \\
\text { приєдналася до Drug, Chemical\&Associated Technologies Association } \\
\text { (DCAT) (DCAT) для того, щоб мати можливість отримати доступ на } \\
\text { ринок США. }\end{array}$ \\
\hline Біофарм & $\begin{array}{l}\text { У жовтні } 2016 \text { р. компанія підписала довгострокову угоду на експорт } \\
\text { своєї продукції до Республіки Смену. }\end{array}$ \\
\hline Здоров’я Груп & $\begin{array}{l}\text { Об’єдналася до співпраці з американською компанією Юнісіті щоб } \\
\text { отримати доступ на ринок США. }\end{array}$ \\
\hline Лекхім & $\begin{array}{l}\text { Компанія - технолог оголосила про плани потроїти експорт своїх } \\
\text { протитуберкульозних препаратів до } 2018 \text { року. }\end{array}$ \\
\hline
\end{tabular}

Джерело: [7]

Слідом за одним із лідерів фармринку - компанією «Фармак», яка в лютому купила дистриб’ютора ліків у Польщі, корпорація «Артеріум» придбала словенську фармкомпанію «Marifarm». Крім створення додаткового експортного майданчика на європейському ринку, українські фармвиробники намагаються таким чином підвищити свою привабливість для іноземних інвесторів [10].

Ефективне здійснення запропонованих заходів, які було виділено на попередніх трьох етапах, неможливе без конкретизації плану дій та комплаєнтного підходу (відповідність бізнес-етиці, внутрішнім та зовнішнім вимогам та правовим нормам).

Проведення n’ятого етапу «Контроль та оцінка» включає в себе: моніторинг результатів реалізації заходів плану бенчмаркінгу та його впливу на основні процеси; обчислення відповідних показників ефективності та оцінка їх зміни; виявлення інших проблем для їх майбутнього вирішення за допомогою бенчмаркінгу. Фармацевтичні лідери-виробники «Фармак» та «Артеріум» досягли своєї межі розвитку в Україні, тому вихід на закордонні ринки шляхом придбання активів є важливим. Основні витрати будуть складатися: в області наукових досліджень та розробок; проведення необхідних експертиз та сертифікацій на підприємстві; проведення маркетингових стратегій для просування товарів на новому ринку; вдосконалення процесів виробництва, з використанням нових технологій.

У країнах СС виробнику з України набагато складніше зареєструвати ліки, ніж місцевому виробнику, тому наявність реєстрацію дочірної компанії в країні ЄС дасть поштовх на розширення кордонів та продажу ліків на європейському ринку. Наприклад, придбана «Артеріумом» фірма «Marifarm» 
орієнтована на контрактне виробництво ліків. Виробничі потужності «Marifarm» дозволяють упакувати більше ніж 750 млн таблеток у рік, тобто приблизно 71500 євро/рік, випускати більше ніж 400 тонн сиропів та інших рідких лікарських засобів. Завдяки купівлі словенської компанії «Артеріум» зможе ввозити нерозфасовані препарати в Словенію, а там вже виготовляти, упаковувати ліки i проводити контроль якості. Цінова політика стане конкурентною на фармацевтичному ринку Свропи, ціни будуть набагато нижче, що буде стимулювати попит. Розвиток виробництва, дистриб'юторської мережі та сертифікація продукції за європейськими стандартами призведе до розширення української продукції на європейському ринку. Угода для «Артеріум» i «Marifarm» - це нові можливості на ринках, що розвиваються, обмін досвідом та застосування досвіду і «ноу-хау» в сфері наукових досліджень, розробок і виробництва продукції. Також це платформа для виходу на європейський ринок, додатковий прибуток та створення нових унікальних препаратів на ринку.

Після проведення запропонованих заходів $\epsilon$ необхідність проведення контролю та оцінки ефективності бенчмаркінгу. Пропоновано здійснювати контроль за наступними показниками: ефективність зовнішньоторговельної угоди; вплив запропонованих заходів на коефіцієнт конкурентоспроможності організації; вплив запропонованих заходів на загальні економічні показники діяльності організації. Також ці показники впливають на конкурентоспроможність організації та на ефективність зовнішньоекономічної діяльності компанії. При оцінюванні отриманого результату варто порівняти реальні показники і прогнозовані.

Висновки. Під час аналізу визначено, що проблемами забезпечення конкурентоспроможності фармпідприємств $\epsilon$ : зростання рівня витрат на дослідження та розробки; значні втрати від операційної курсової різниці; зменшення рентабельності товару та рентабельності продажу продукції; погіршення ефективності проведеної реклами. В цілому, до конкурентних перевагам фармпідприємств на світовому ринку віднесено: сильна маркетингова стратегія, концентрація на брендових препаратах, порівняно низькі ціни та висока якість підтверджена міжнародними сертифікатами, експорт якісних та високотехнологічних лікарських препаратів, ефективний портфель лікарських препаратів.

Оскільки бенчмаркінг передбачає неперервний процес ідентифікації, адаптації та реалізації рішень, які призводять до значного покращення діяльності підприємства, представлено алгоритм бенчмаркінгу конкурентоспроможності для вітчизняних фармпідприємств.

Новизна дослідження полягає в удосконаленні проведення бенчмаркінгу фармацевтичних компаній при виході на європейські ринки 3 урахуванням галузевої специфіки. Практичне значення дослідження полягає в можливості розвитку зовнішньоекономічної діяльності підприємства фармацевтичної галузі 3 використанням бенчмаркінгу для підвищення 
конкурентоспроможності підприємства на зовнішніх ринках. Подальші наукові дослідження буде присвячено комплаєнтному підходу бенчмаркінгу.

\section{Література:}

1. Мехеда Н. Г., Гладун Я. І. Застосування бенчмаркінгу та проблеми його розвитку в Україні URL: http://www.rusnauka.com/6_PNI_2013/Economics/6_129925.doc.htm.

2. Довгань Л.Є., Каракай Ю.В., Артеменко Л.П. Стратегічне управління: Навчальний посібник. К. : Центр учбової літератури, 2011. С. 372-387.

3. Артеменко Л.П., Демченко П.О. Проблеми застосування бенчмаркінгу в Україні. Сучасні підходи до управління підприсмством: Збірник тез доповідей VII Всеукраїнської науково-практичної конферениії з міжнародною участю, 28 квітня 2016 р. К.: Вид-во «Політехніка», 2016. С. 69

4. Pichugina M.A., Artemenko O.T. Benchmarking as Attribute of Entrepreneurship. Сучасні підходи до управління підприємством: зб. тез. доп. VII Всеукраїнськоі наук.-практ. конф., 6 квітня 2017. Київ: КПІ ім. Ігоря Сікорського, Вид-во «Політехніка», 2017. с. 11.

5. Petuskiene E., Glinskiene R. Entrepreneurship as the Basic Element for the Successful Employment of Benchmarking and Business Innovations. Inzinerine EkonomikaEngineering Economics. 2011. vol.22, iss.1.pp. 69-77.

6. Special Edition: 2016 FY Results. Ukrainian Pharmaceutical Market Monthly. 2017. P. 515 URL: www.upharma-c.com

7. Фармбізнес: висновки 2016 - очікування 2017: результати конференції. URL: https://www.legalalliance.com.ua/ukr/novini/u-kievi-vidbulasa-konferencia-prisvacenareguluvannu-farmacevticnogo-biznesu/

8. Мировой рынок рецептурных препаратов: прогноз до 2024 г. - 2017 p. URL: https://www.apteka.ua/article/463742

9. The European Federation of Pharmaceutical Industries and Associations. The Pharmaceutical Industry in Figures, 2013. EFPIA URL: : http://www.efpia.eu/uploads/Figures_Key_Data_2013.pdf

10. Майзус С. Фармацевтичний бізнес у Словенії. Полтава 365. 2016. URL: http://poltava365.com/4487-zhevago-pridbav-farmaczev.html 